\title{
Sport tourism: an opportunity for local regions in a global context. A Delphi study \\ Turismo deportivo: Una oportunidad para los territorios locales en un contexto global. Un estudio Delphi \\ *María del Pilar Leal Londoño, **Raúl Travé Molero, ***F. Xavier M edina, ****Sixte Abadia Naudí, **Sheila Sánchez Bergara \\ *CETT-UB (España), ** Ostelea (España), ${ }^{* * *}$ U niversidad 0 berta de Catalunya (España), ****U niversidad Ramon Llull (España)
}

\begin{abstract}
This study is a research project that focus on the opportunities offered by sport tourism to invigorate local regions in a global context. Primary research data were collected through a Del phi method applied to a panel of 20 international experts on sport tourism worldwide. The results reveal that, in order to grow and become a development tool in tourism destinations, sport tourism activities need to be organised in close cooperation with sport and tourism agencies, decision makers and the local community. M oreover, that the cooperation between agencies of tourism and sport is essential to ensure the success of a sport tourism destination.
\end{abstract}

Keywords: Sports, Tourism, Sport tourism, local development, Delphi method.

Resumen. Este estudio es un proyecto de investigación que se centra en las oportunidades que ofrece el turismo deportivo para dinamizar las regiones locales en un contexto gl obal. Los datos de la investigación primaria se recopilaron mediante un método Delphi aplicado a un panel de 20 expertos internacionales en turismo deportivo. Los resultados revelan que, para crecer y convertirse en una herramienta de desarrollo en los destinos turísticos, las actividades de turismo deportivo deben organizarse en estrecha cooperación con las agencias de deporte y turismo, los actors encargados de la toma de decisiones y la comunidad local. A demás, se señala que la cooperación entre agencias de turismo y depor te es fundamental para asegurar el éxito de un destino de turismo deportivo.

Palabras clave: deportes, turismo, turismo deportivo, desarrollo local, método Delphi.

\section{Introduction}

Sport has become an increasingly common practice for society. At the same time, it has also become a common leisure alternative for an increasingly broad social spectrum. Along with tourism, it has become one of the most popular leisure practices in the contemporary world. As the World Travel \& Tourism Council (2019) points out, travel and tourism are «one of the world's largest economic sectors, supporting one in 10 jobs (319 million) worldwide and generating $10.4 \%$ (US\$8.8 trillion) of world GDP in 2018.

The intersection of the two spheres, the physical and sporting activities linked to tourism, isalso becoming an element of significant importance linked to specific local development projects; and especially in inland regions and territories where its combination with cultural tourism and / or natural environment, for example, can give very interesting results. In thisregard,

Fecha recepción: 30-12-20. Fecha de aceptación: 08-03-21

F. Xavier Medina

fxmedina@gmail.com the Da Nang Declaration on Promoting Tourism and Sport for Sustainable Development, created in 2016, says that tourism and sports also represent the most powerful economic driving force of society today with enormous potential to generate a very wide-range of socio and economic spin-offs (UNTWO, 2016).

Moreover, sports linked to tourism represents the fastest growing sector in global tourism as several $N$ ational Tourist 0 ffices (NTOs) are working towards promoting their destinations focused on sports. According to Pigeassou (2004), sport tourism appears as a combination of services as well as a set of services presented or sold in various ways. As the author stated out, the more common indicators of these experiences are: type of activities, level of expertise, and investment in the activity, context and status of the participants. However, nowadays a deep discussion and analysis about what sport tourism is, its modalities and its impacts on destinations worldwide is needed.

The aim of this paper is to explore, according to sport tourism experts panel compared with the existing literature, the link between sports and tourism and its opportunities as a driver of development for local destinations avoiding the most common negative 
impacts and legacies and maximizing the positives ones (Kim \& Gursoy, 2006; Ziakas, 2010; Gonzáles \& López, 2017; Kirby, Duignan \& M cGillivray, 2018; Peric, 2018; McGillivray, Duignan \& M ielke, 2019; M air et al ., 2021; etc. ), in agreement with the guidelines set by theW orld Tourism O rganization after its resolution 364(XII) of the UNTWO General Assembly held in Istanbul (Turkey) in 1997, and al so with the Global Code of Ethics for Tourism (1999). To achieve this, the research, based on the application of the Delphi M ethod to international sport tourism experts, provide insights on two main axes: (1) the economic and social impact of sport tourism in destinations and (2) public and private cooperation strategies for promoting sport tourism in destinations. Finally, the results based on a gl obal perspective highlight the main opportunities and barriers for sport tourism and new trends and its perspectives for this relevant phenomenon.

\section{Sport and Tourism in academic literature: An introductory review}

The definition of sport tourism has been an issue throughout the short history of this field, and it still can generate lively discussions among academics and professionals. The first academic publication on sports tourism appeared in 1966 thanks to the British Central Council for Physical Recreation (Anthony, 1966). In 1970, W illiams and Zelinsky studied the generation potential of mega-sport events. During the 1980s, academics focused on the economic benefits of this kind of sport events. Since the nineties, the field has grown and diversified its interest, although the definition of this field is still somewhat confused, and as Gibson predicted in 1998, it has grown in afragmented manner, both as an academic field of study and as a distinct component of the tourism industry.

Sport tourism was primarily considered only related to trips to witness sport events. Redmond (1990-1991) pointed out that spectators were only one type of sport tourist, and described sport participants and visitors to sports attractions (i.e., famous stadia and halls of fame) al so as actors of sport tourism. Hall (1992) divided sport tourism in two big types of behaviours: travelling to observe sports and travelling to participate in sports. Following these definitions, we can glimpse three different kind of destinations: those that host a sport event; those that offer the possibility of practising a given sport activity, and those that offer some attraction related to sports.
But Pigeassou (1997: 29) affirmed at the end of the nineties of the last century that the tourist sport was al ready in a phase of defining its identity. But it happened slowly, and only in some countries. As an example, in the case of Spain and regarding the field of social anthropology, we havethat in the 1990s, gamesand sports was among the most prominent study categories of the decade. However, within it, the subcategory that links sports and tourism does not appear (M edina \& Sánchez, 2002, 2006). Authors such as Standeven \& De Knop (1999) pointed out the growing relationship symbiotic between both phenomena (sportsand tourism), of which its processes of massification, complexity and diversification are parallel in time and feedback from the same dynamics than society itself. An interesting example of this phenomenon can be that of popular athletic events (urban races, marathons or half marathons, solidarity races, etc.), which are today an important attraction for travelers who organize their leisure around of these events(Abadia, M edina, Sánchez, Sánchez, Bantulà \& Morejon, 2016; Abadia, Cabedo, Sánchez, M edina, M oragas \& M orejón, 2019).

In 1998, Gibson gave probably the most accurate and comprehensive definition of sport tourism, as a «Leisure-based travel that takes individuals temporarily outside of their home communities to participate in physical activities, to watch physical activities, or to venerate attractions associated with physical activities» (Gibson, 1998, p. 49).

W ith this definition, Gibson unifies the aforementioned and indicates three different subcategories of sport tourism: Active Sport Tourism, Event Sport Tourism and Nostalgia Sport Tourism. Accordingly, we can use this definition to think about three ideal types of destinations.

In 2002, Gibson insisted on thisidea, describing sport tourism as a trip with the purpose of a) taking part of, b) watching, or c) venerating or celebrating sport (2002, p. 115). In this way, sport tourism reveals itself as «a unique area of study derived from the interaction of activity, people and place [... ] an activity in its own right, related, but not subordinate to sport and tourism» (Weed \& Bull, 2004: 15). Along this same regard, Standevan (1998: 42) noted that sport tourism should be understood as a two-dimensional concept: Sport, «a cultural experience of physical activity» and tourism «a cultural experience of place».

Van Rheenen, Cernaianu \& Sobry (2016) highlight five dominant underlying dimensions in the definitions of sport tourism: time (the length away from a home 
environment), space (encompassing travel away from a home environment), sport as a motivation for travel (type, level and extent of sport activity), participating experience of the sport tourism activity and economic motivation. The most present dimension among the definitions analyzed was the one of sport as motivation for travel.

There are, nevertheless, multiple ways of categorising sport tourism. Lisbona, M edina \& Sánchez (2008), differentiate between sport during holidays, involving sports activities performed while on a tourism trip, which can enrich the offer of a particular destination, but is not the central attraction; and sport holidays, those that implies sport as the main aim of the trip. This kind of tourism is relatively recent and still representsan oppor tunity to new, stagnated and declined destinations. M oreover, those authors (2008: 166) point out that we could even distinguish the purposes of the last type between competition sport and recreational sport. However, they admit that above all the differentiations, sport tourism includes every one of the contemporary aspects of leisure, such as recreational, environment-ecological, creative, festive, volunteer, etc.

Nowadays, most academics agree that there are mainly three different types of sport tourism behaviour: 1) actively participating (Active Sport Tourism), 2) spectating (Event Sport Tourism), and 3) visiting and, perhaps, paying homage (N ostalgia Sport Tourism) (Gibson, 1998b).

According to this, De Knop (1990) identified three types of active sport vacations: 1) the pure sport holiday (such as a trip to go skiing); 2) taking advantage of the sport facilities at a holiday destination, although sport is not the primary purpose of the trip; 3) the private sporting holiday, where tourists take part in nonorganised sports activities (such as volleyball on the sand or beach cricket).

It is quite interesting to highlight, as Weed (2009) did, how for a longtime academia focused on sport and holidays impoverishing the outlook and leaving the relations between tourism and sport unnoticed. Many authors have asked themselves if sport tour ism can work as a catalyser for other resources; if it is necessary to have a wider offer as complement or if a sport offer is enough to make a destination interesting (Fernández \& Gutiérrez, 2014). 0 ther authors stated that sport tourism can be a tool against seasonality or to improve and differentiate destinations improving competitiveness (Kenelly \& Toohey, 2014). Along with this, organising sport activities in different places of aregion can improve the distribution of the offer or help to decongest an overcrowded destination, while strengthening the development of alternative tourism options (M edina \& Sánchez, 2005).

Those kinds of problems prove that there is a real need for collaboration between public and private agents in the field of sport tourism to avoid irreparable consequences and ensure a fair distribution of costs and benefits (Jackson \&Weed, 2003; Weed \& Jackson, 2008; Chalip, 2004; Weed, 2009). As H inch \& Higham (2011: 63) points also out: «The achievement of sustainable sport tourism requires a balance between social, economic and environment goals», and the approach known as the «triple bottom line».

New activities can arise from surprising coalitions in the fields of sport tourism and cultural heritage in some destinations. Nevertheless, sport is a cultural creation and it can be an element of local identity at the same time as a tourist attraction; this is the case of ethnic and traditional sports such as Basque pelota (GonzálezAbrisketa, 2005) or Canarian wrestling (Alonso \& M edina, 2019). Both have been recognised as cultural reference pointsand important tourist attractions, shown as unique and exclusive, and in the end they have been recognised as cultural heritage in order to use them as tourist attractions. The recognition as cultural heritage of these traditional sports can improve the offer in many destinationsand they can specially be assetsfor peripheral and marginalised areas, but as with every heritagization process, they can cause undesirable consequences such as breaching the continuity in the cultural production of meanings(Nogués-Pedregal, Travé-M olero \& CarmonaZubiri, 2017).

Academics have been long concerned about the effects of hosting different types of sport events for a particular community, along with the competition between cities to attract the most lucrative sport events (Turco \& Eisenhardt, 1998; M edina, 2006; Weeds, 2008; Yildiz \& Çekiç, 2015). Researchers on sport tourism commonly agree that small-scale local events have a bigger impact, both on the economic income and the mental wellbeing of the residents (Higham, 1999: 87). W hen talking about small-scale events, locals are more likely to cooperate in the organisation and with the consequent new feeling of pride in the community. M oreover, this kind of event tends to improve the general attraction of the destination, to strengthen its competitiveness and to promote tourism beyond the event itself. In this way, people may return to a particular place for a holiday after attending (or watching on 
television) a sport event there (Higham, 1999: 87). Closely related to small-scale events, community-based mass participant sport events, as running (Zhou \& Kaplanidou, 2018) or M BT events (Nogueira, Farías \& Pereira, 2021) tend to generate a more positive perception of the impacts and legacies among the host communities. Moreover, they have the potential to build social and bonding capital among participants, organizers and other social actors and therefore «to contribute to the community development and wellbeing» (Zhou \& Kaplanidou, 2018: 491)

Academics usually describe small-scale events as those that take place during the regular season of competition sports, regular international competitions, local or regional competitions, competitions for the disabled, etc. This kind of event does not require big investments; they tend to use previous infrastructures; they are easy to manage regarding visitors and they help dealing with seasonality (Higham, 1999: 87). On the contrary, when speaking about megarevents, the positive effects to local residents are much more debatable. U sually this type of event lasts just for a short period of time and it can generate an important amount of debt for the local budget. It can also bring about the beginning of corruption processes and displacement for some members of the community as a result of the development of new infrastructures. (Walo, Bull $\&$ Breen, 1996).

The success of a sport event and its tourism consequences will be proportionally related to how it fitsin among the organisers and the local social structure (W äsche, 2015). Especially nowadays when social involvement and even public referendums (Scheu \& Preuss, 2018) could be a legal requirement or at least an institutional recommendation, as we can see in the O lympic 2020 Agenda (IO C, 2018). According to W äsche (2015) the most fruitful and long-lasting relation will be that between actors of a similar size, similar organisational culture and the same objective -lucrative or not. In this regard, Hinch \& Higham (2011) points out that «sport tourism partnershipsshould be established and operationalised in a way that a mutually beneficial». These alliances have to be based on mutual benefit and all the actors must be involved in the projects for their own good, without any feeling of subordination (Kenelly $\&$ Toohey, 2014). Along these lines, Fredline (2005) tackled residents' experiences and perceptions must be incorporated into the strategic planning process and he insists on the importance of consulting the impact of sport tourism developments with the local population.
If all this happens, the public image of the destination will quite probably experience an important improvement (Kim, Jun, Walter \& Drane, 2015).

$O \mathrm{n}$ the other hand, impacts and legacies of mega sport events tend to be perceived as socially problematic (Thomson et al., 2019; M air et al., 2021). Not only the perception of the negative legacies usually outweighs the positive (Scheu \& Preuss, 2018: 378) but theinterests of micro and small business are normally sidelined, even when these are used as central to legitimize the events (Kirby, Duignan \& M cGillivray, 2018: 917). It is quite significant that Olympic Games had become a paradigmatic example of negative socio-economic and urbanistic impacts in the host community (M cGillivray, Duignan \& Mielke, 2019). N evertheless, we can find counterexamples which show a high grade of perceived positive socio-economic impacts (Peric, 2018; Lesjak et al. 2014; Cabanilla et al., 2021), although these cases are related with minority sports or with regional/ national level events.

Mixed with other types of tourism, sports activities can be a tool in broader projects of local development. An example of thisis the use of adventure sport activities as a means of modernisation and development in rural or peripheral areas (Lisbona, M edina \& Sánchez; 2008). In these cases, private-public collaboration could be essential to be successful, along with a correct implementation of actions, plans and local development strategies (M edina \& Sánchez, 2005). This collaboration may be critical regarding infrastructures in peripheral destinations (Fernández $\&$ Gutiérrez, 2014). This relationship between public and private stakeholders was highlighted by the World Tourism 0 rganization (UNTW O, 1999) through the Global Code of Ethics for Tourism, considering that this genuine collaboration between agents was essential for the development of tourism.

A metaranalysis of the existing literature on sports tourism conducted also by Weed (2009) confirmed the predominance of articles on sporting events, a change in approach in the research focusfrom leveraging impacts and concerns about quality of behavioural research in this field. This author concluded that research in the field of sports tourism began to show signs of maturity. Given that most of the research shows a methodological homogeneity, it is necessary to broaden the methods to obtain better results. For this purpose, Weed (2006) suggests enhancing the field of sport tourism with a bigger epistemological and methodological heterogeneity. In this way, the use of the interpretative 
paradigm could improve the comprehension of the process and the associated behaviours.

O ne decade after Gibson, Weed (2009) pointed out the persistence of a good number of problems in the field of sport tourism such as:

«A lack of coherence in research relating to sports tourism; alack of agreement about fundamental concepts and assumptions about the nature of the relationship between sport and tourism; the range of perspectives of (or taken by) reviewers; the aims and objectives of the reviews; and the nature of the processes of reviewing and/ or synthesising research itself» (Weed, 2009: 615).

Currently, as Kenelly \& Toohey argue (2014) it is quite frequent to find a lack of relations between the different sectors of tourism and sport. As a matter of fact, in 2001 theWorld Tourism O rganisation itself and the International Olympic Committee held a joint conference to discuss the relationship between sport and tourism and the introductory report (Keller, 2002) did not mention any of the previous and recent research evidence found by Gibson (1998) andWeed (1999).

In addition, there is aneed to study the consumption patterns regarding sport tourism and a broader understanding of the impacts of sport events in the host communities (Jiménez-Naranjo, Coca-Pérez, Gutiérrez-Fernández \& Fernández-Portillo, 2016). Additionally, from the academia, we need to determine the variables (internal and external) that can explain the bigger expenses of those who practise sport tourism (Jiménez-N aranjo, et al., 2016). In this way, we could open up new and fruitful lines of investigation, such as: 1) developing comparative studies between different types of sport events with their socio-economic impacts; 2) developing comparative studies between the socioeconomic impacts of sport events in different host cities (Jiménez-Naranjo, et al., 2016). W ith another perspective, Weed and Bull suggest that "a framework that considers impacts may be a little outmoded" and that the concept of leveraging can act as abridge between research on behaviours, impacts, policy and provision "and for this reason it seems that such leveraging approacheswill play acentral part in future sport tourism research" (2004: 43).

What we cannot forget is that sport tourism itself is becoming a global trend. Therefore, the greatest opportunities come from attracting the attention of new targets. Women and disabled people are probably the most important future targets for sport tourism.

Although sports and activities of sport tourism have been a male-orientated field for many years (Humberstone, 2000), the fact is that the number of women interested in watching and practising sport has been constantly growing over the last couple of decades, along with the number of young adults involved in sport tourism. Joining these objective targets is an important part of the tourism business nowadays.

Disabled people have al so become a new target for tourism in general -although the academia has not paid too much attention to this phenomenon (Cruces, 2016) and sport tourism in particular. In order to improve our understanding about sports tourism and disability, it is extremely important to study the needs of this type of tourist, especially everything about the destination experience and the appropriate accommodation (Darcy \& Dickson, 2009). In this field, the majority of the research is related to the involvement of disabled people in leisure trips, the attitudes and education regarding leisure of disabled people and disabled people's perception of sport.

All in all, sport is gradually changing some aspects of the tourism offer. For example, professional athletes are a growing market for destinations; events are being used to improve the public image of several places; new ways of tourism and sport are being found and are becoming not only popular, but turning into mass phenomenon and new companies are being set up to offer new sport tourism services (Latiesa \& Paniza, 2006).

\section{Methodology:The Delphi Method as a tool to explore the link between sports and tourism and its opportunities}

\section{General considerations on the Delphi Method}

The Delphi method as a research approach was introduced in the late 1940s. The main premise of the Delphi method is based on the assumption that group opinion should be more valid than individual opinion. In this sense, the Delphi technique has been defined as a multi-staged survey which attempts ultimately to achieve consensus on an important issue (McKenna, 1994).

Following Linstone \& Turoff (2002: 3), the Delphi method may be characterized as a technique for structuring a group communication process so that the process is effective in allowing a group of individuals, as a whole, to deal with a complex problem. To accomplish this «structured communication» there is provided: some feedback of individual contributions of information 
and knowledge; some assessment of the group judgment or' view; some opportunity for individuals to revise views; and some degree of anonymity for the individual responses.

Following the same authors (Linstone \&Turoff, 2002: 5; Hsu \& Sandford, 2007: 1-2), the most common Delphi processisthe «conventional or classical Delphi» version, where a small monitor team responsible of the research designs a questionnaire which is sent to a larger respondent group of experts having knowledge of the area requiring decision making. After the questionnaire is returned, the monitor team summarizes the results. After this step, and based upon that results, the monitor team develops a new questionnaire for the respondent group and restart the process. The respondent group is usually given at least one opportunity to re-evaluate its original answers based upon examination of the group response.

As H su \& Sandford (2007 1) points out, the Delphi technique is well suited as a method for consensus-building by using a series of questionnaires delivered using multipleiterationsto collect datafrom a panel of selected subjects. Thorough pre-planning and rigorous management of the survey, the Delphi technique can provide information that other conventional extrapolative methods cannot reliably forecast (Cunlife, 2002: 31; Sánchez-Bergara et al., 2018).

\section{The Delphi Method as a useful tool in our research}

In order to contribute to a better understanding of the link between sport and tourism and its future implications, across-dimensional approach was designed (Sánchez-Bergara, et al., 2018). In a first phase, an indepth review of academic papers, sectorial and institutional reports were conducted. After that, a first draft was elaborated where the last detected tendencies and novelties on sport tourism were identified. This draft was used to apply the Delphi Method to sport tourism experts around the world. This method was chosen because despite there being an important scientific production on sport tourism on a global scale, there is a need for an in-depth discussion on issues relative to the opportunities and the future of this phenomenon. Moreover, the paper seeks to create a consensus about the challenges, opportunities and perspectives of sport tourism and to do that the Delphi Method is a very useful.

In designing the Delphi survey, a panel of experts was identified based on the literature review conducted and the suggestions made by the World Tourism Organization (W TO). The criteriato choose the experts was based on their practical and/ or academic experience and knowledge on the topic. Firstly, forty-five respondents from Spain (46\%), U nited States (15\%), Australia(12\%), Malaysia(7\%), England (5\%), Thailand $(5 \%)$, Brazil (2\%), Mexico (2\%), Belgium (2\%) and Germany $(2 \%)$ with experience in sport and tourism were selected and contacted by email, inviting them to collaborate in the study. The Delphi iterative questionnaire survey process was conducted online. The survey was structured in sections: 1) Section I. Sport tourism projects and their regional link; 2) Section II. The impact of sport tourism projects; 3) Section III. O pportunities of sport tourism projects and 4) Section IV. The academic approach.

All the questions were multiple-choice. The first round was developed between January 24 and February 8 of 2017. Twenty panel members replied to the first iteration providing a response rate of $47.61 \%$. From their responses, the ones most voted were selected for inclusion in the second round D el phi questionnaire. The second round was conducted between February 13 and February 27 . The second questionnaire was sent to the twenty panellists who answered the first round. Fifteen panel members replied to the second iteration, which means a response rate of $75 \%$ in which $66.6 \%$ were from Europe; $20 \%$ were from theAmericas and $13.3 \%$ were from Asia and the Pacific. All the answers received were valid. The majority of respondents represented private sector businesses (33.3\%), governmental Departments (26.6\%) and educational institutions (40\%). The information gathered is incorporated along the paper.

\section{Results: Exploring opportunities in sports and tourism}

Theempirical findingswere based on the information gathered. Thus, this section presents the results obtained based on the Delphi method and the secondary information. Moreover, this section presents not only the issues that are identified by this study but also postulates the linkages between the empirical findings and the literature discussed.

\section{Ensuring the success of sport tourism in destinations}

Based on the answers provided by the panel of experts, the majority of responding believe that the 
cooperation between tourism and sport agencies $(86.7 \%)$, proper communication and transportation infrastructuresand suitable equipment/ facilities (73.3\%) and the expertise of the bodies and their social, business and institutional network (60\%) are the three most important criteria for ensuring the success of a sport tourism project in a destination. Figure 1 presents the percentage of each possible answer to this topic.

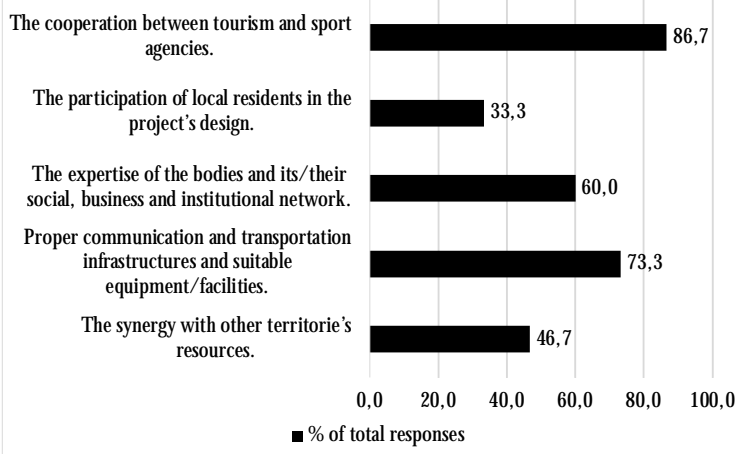

Figure 1. Which are the three most important criteria for ensuring the success of a sport tourism project in a destination?

Source: Author's own elaboration.

In regard to the second question related to the three major obstacles to running a sport tourism project in a region, the greatest consensus was for: 1) lack of coordination between public tourism policies and the decision makers $(80 \%) ; 2$ ) the costs of the project's design, implementation and execution (66.7\%) and; 3) lack of coordination between the sport and tourism authorities (joint working) (60\%).

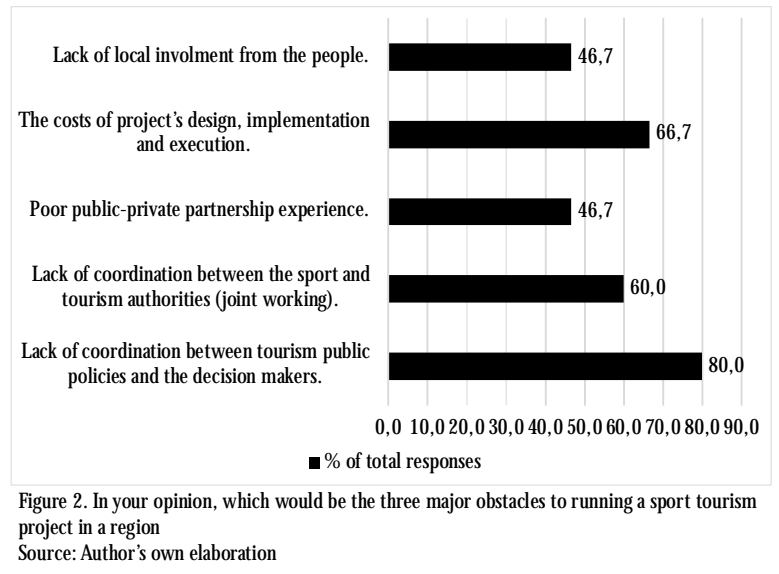

Figure 2 shows second round answers to this subject. In this regard, it is important to highlight that the lack of local involvement from the people and the poor public-private partnership experience were considered as important obstacles for almost the $43 \%$ of the respondents.

\section{The impact of sport tourism projects}

Regarding the impact of sport tourism projects, the majority of responding experts consider that the main benefits of sport tourism for a region are: 1) a possible solution to the seasonality dependence in tourism regions $(80 \%)$; 2) a new driver for local development (wealth and employment creation) (73.3\%) and; 3) possible synergies with other activities (60\%). Furthermore, more than $50 \%$ of the respondents mentioned that the income for the hospitality industry and others tourism companies is another important benefit of sport tourism activities.

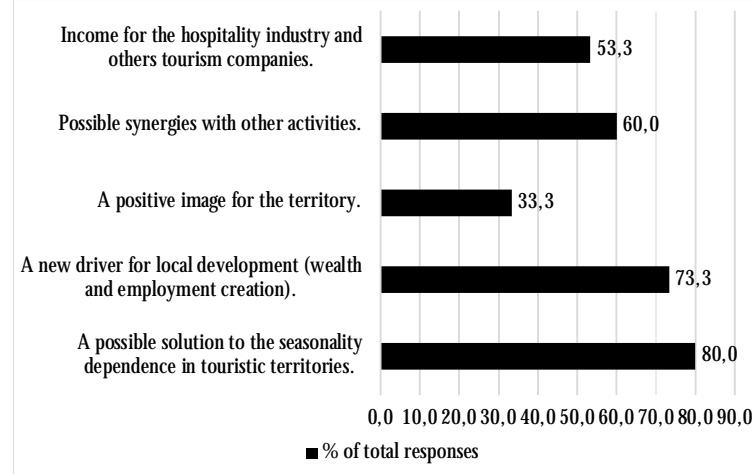

Figure 3. In your opinion, which could be the three main benefits that the activities linked to sport tourism in a territory could bring? Source: Author's own elaboration.

Concerning the second question related to the three main negative impacts that sport tourism projects could cause in a region, respondents were unanimous: the expensive and underused infrastructures are the main negative impact (100\%).

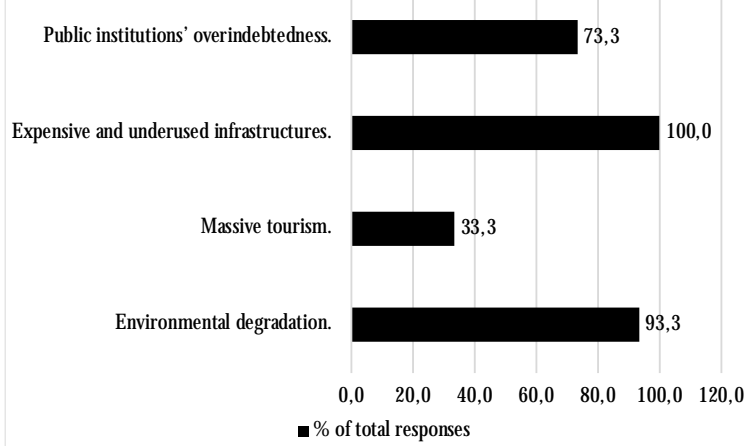

Figure 4. In your opinion, which would be the three main negative impacts that sport tourism projects could cause in a ter ritory?

Source: Author's own elaboration.

Moreover, environmental degradation (93.3\%) and public institutions' over-indebtedness (73.3\%) are considered the second and third most important detrimental consequences of sport tourism projects. Figure 4 includes the percentages of responses to each answer on this topic.

\section{Opportunities of sport tourism projects}

In regard to which would be the key opportunities 
for sport tourism, the greatest consensus was for: an increase of small-scale sport events in order to improve the local economy (93.3\%). W ith respect to a stronger synergy and coordination between companies from different fields in order to develop activities related with sport tourism, this issue was considered as the second main opportunity (73.3\%) that sport tourism would boost.

Finally, longer term stays linked to sports events was chosen as the third key potentiality with $53.3 \%$ of responses (see figure 5).

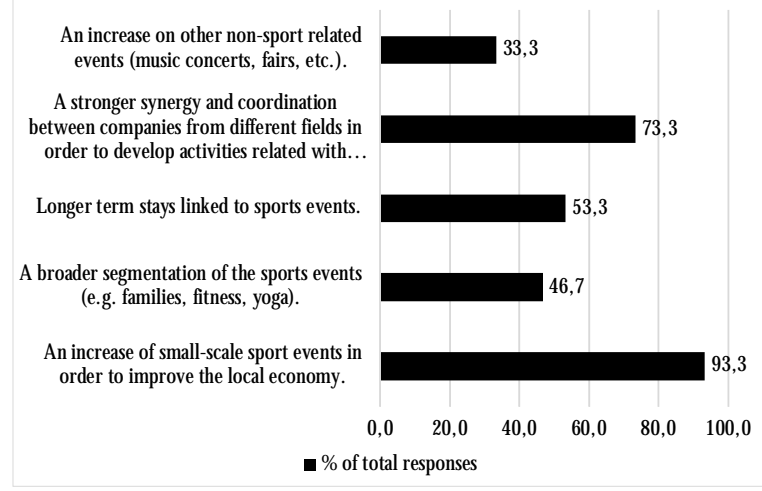

Figure 5. In your opinion, which would be the three main opportunities for sports tourism? Source: Author's own elaboration.

\section{The academic approach}

From the academic point of view, there are important constraints related to the study of Sport Tourism (see Figure 6). On the one hand, a lack of coherence in the approaches made so far between tourism and sport separately (86.7\%).

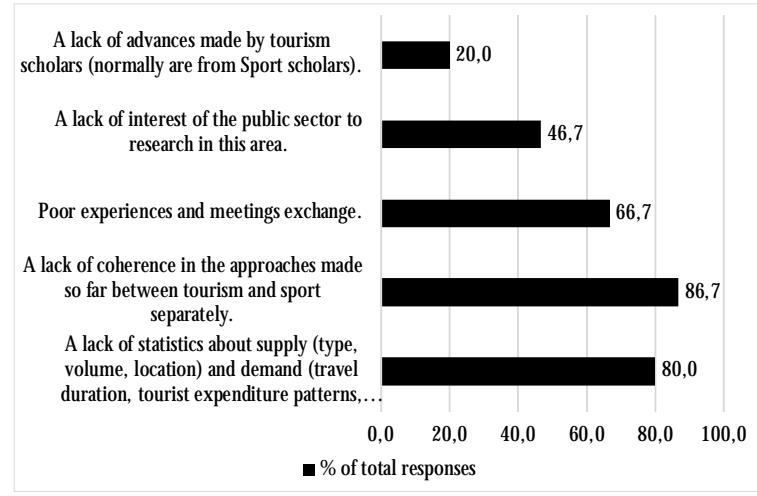

Figure 6. Which would be the three main constraints related to the study of SportTourism? Source: Author's own elaboration

In addition, a lack of statistics about supply (type, volume, location) and demand (travel duration, tourist expenditure patterns, seasonal, travel organization, visitor profile) (80\%). This situation affects knowledge production and limit exchanges between academia and industry. Moreover, $66.7 \%$ of the consulted experts coincide that poor experiences and meeting exchange is another important limitation to expanding the study of Sport Tourism.

\section{Discussion and conclusions}

This study has attempted to contribute to the knowledge and discussion around the opportunities and the future of sport tourism. In this regard, and according to UNW TO (2016), the different agents involved in the management of sports tourism must ensure to "Create adequate and responsible conditions for the sustainable and successful development of natural, cultural, human and built resources to enable the fruitful growth of tourism and sports for socio-economic benefit».

Throughout the information gathered based on a panel of experts located in the five continents, it could be seen that cooperation between different administrations, scholars, decision makers, businessand sectors is the most important concern of the international panel members. Therefore, the main conclusion would be that, in order to grow and become adevelopment tool in tourism destinations, sport tourism activities need to be organised in close cooperation with sport and tourism agencies, decision makers, other local resources, the local community, etc. This position is also supported by Hinch \& Higham (2011) in highlighting the importance of partnerships and strategic alliances in sports tourism, largely due to the great diversity of stakeholders involved. $\mathrm{n}$ the other hand, it was found that experts do not acknowledge enough importance to the involvement of local communities in sport tourism projects, from our perspective and according to most of the scholars, this is a mistake that should be taken into account.

In this regard, the first section of the survey applied found that for the international panel experts the cooperation between agencies of tourism and sport is essential to ensure the success of a sport tourism destination. Although other issues raised an important attention among the experts, such as the need for proper infrastructures and the expertise of the social, business and institutional actors involved in a given sport tourism project. However, the lack of importance given to the participation of local residents in the project's design should be pointed out as worrying, contrary to what is normally outlined by social researchers.

W hen the panel experts discuss about the major obstacles to running successful sport tourism projects, the main problem indicated is again related to the 
cooperation between the different actors involved. In this case, the panel indicated the lack of coordination between tourism public policies and the decision makers (highlighted also by Hinch \& Higham, 2011). Those authors claim that until a few years ago, partnerships in the field of sports tourism have been quite ineffective, largely due to lack of conscious integration by policymakers, planners and public providers at national level. Close to this concern, they place as the second most important problem the possible costs of design, implementation and execution of the projects.

The third problem in importance for the experts is the lack of coordination between the sport and tourism authorities, clearly related to the need for cooperation between agents that we are pointing out as the most relevant conclusion of the survey.

Once more, the involvement from the locals was not seen as one of the most important factors in the development of a sport tourism project. O nly $46.7 \%$ of the participants in this survey thought that the lack of local involvement could be an obstacle to running a project in a given region. The same percentage pointed to a poor public-private partnership experience as an obstacle. As previously mentioned, the raising of awareness about the central role of locals to achieve not only the success, but also the sustainability of sport tourism projects would improve the results and the sustainability of the destinations, in line with article 3 of the Global Code of EthicsforTourism (UN), according to which «All the stakeholders in tourism development should safeguard the natural environment with a view to achieving sound, continuous and sustainable economic growth geared to satisfying equitably the needs and aspirations of present and future generations».

When asking about the positive impacts of sport tourism projects (section II of the survey), the panel experts highlighted (in this order) sport tourism as a solution to seasonality; asadriver for local development; as a new element to create synergies with other activities; as a source of income for the local economy, and last but not least, they chose the creation of a positive image for the region. This classification is a reflection of the main concerns about tourism destinations, with seasonality and the need for social and economic development as the most important, shared problems in most of the tourist destinations all around the world.

On the other hand, the negative impacts of sport tourism throughout the destinations outlined by the panellists are the high cost and the underuse of infrastructures. This is such a big problem that it was unanimously chosen by the entire panel. The environmental degradation was also considered as one of the main threats in a sport tourism destination. Closely related to the cost and underuse of infrastructures the majority of the experts consider that the over-indebtedness of the public institutions could have a negative impact on sport tourism projects in the region. Finally, 33.3\% consider the widespread growth of tourism as a real negative impact derived from sport tourism. These answers show the reality of an important part of the sport tourism destinations, where the investment in expensive facilities will need too many years for a return to be obtained, if ever, and the public administrations are seriously over-indebted. Likewise, environmental degradation is a reality in some of the most successful destinations, such as ski resorts or golf resorts. Nevertheless, the transformation of sport tourism destinations into mass tourism destinations is not a very common issue.

On the other hand, regarding the opportunities offered by sport tourism is clear that the increasement of the small-scale sport events area a way to improve the local economy. Moreover, a stronger synergy and coordination between companies from different fields in order to develop activities related with sport tourism could be a great opportunity. The possibility of longer stays in the destination thanks to sports events is seen also as an opportunity.

Nevertheless, as part of the barriers is worth to mention the need for coordination between actors and the transformation of this cooperation into positive synergies. In addition, the main constraint still the lack of coherence in the approaches made so far between tourism and sport separately. Following this, the lack of statistics about supply and demand is al so seen as a major problem. From these results, we must practise a heal thy self-criticism and recognise that as scholars we have to listen to the needs of the social agents. In this sense, we should improve the coordination between the fields of tourism and sport and provide quantitative and qualitative tools in order to make progress in the definition of the consumers and their preferences.

Finally, and based on the main purpose of this research: to explore the sport tourism and its opportunities as a driver of development for local destinations based on the information provided by an international panel of experts on this subject, we can argue that sport tourism can still making a great contribution to local destinations if mechanisms of participation, interaction and cooperation between all stakeholders take place. 
Moreover, and based on the literature review, we witnessed how sport and tourism are closely linked, historically and socially. However, and based on experts' opinions and the scientific literature reviewed, we have highlighted agreements and disagreements that should be helpful both for scholars and specialist in order to maximize positive socio-economic impacts and legacies and minimize the negative ones.

The authors consider that the current study provides an exploratory approach on the topic. Therefore, we are aware about the main limitations and barriers of this research which has been the scope of the expert's panel which is limited and there is a need to increase the geographical scope. Moreover, and as part of the future research lines, we consider that the cooperation and participation mechanisms of local stakeholder on the destinations needs to be explore and discuss in depth since are relevant factors of local and spatial development.

\section{References}

Abadia, S., Cabedo, J., Sánchez, R ,, M edina, F. X., M oragas, M. \& Morejón, S. (2019). Exploring Charity SportEvents in BarcelonaProvince: A Phenomenon on the Rise, abeit with Pending Issues. Retos Nuevas tendencias en educación física, deportesy recreación, 35:229-235.

Abadia, S., Medina, F. X, Sánchez, R, Sánchez, J., Bantulà, J. \& M orejón, S. (2016). Empresa, deporte y solidaridad: el caso de 0 xfam IntermónTrailwalker. Revista Internacional del Ciencias del Deporte(RYCIDE), 12 (44): 149163.

Alonso, V. \& Medina, F. X. (2019). Antropología, deporte y turismo: Reflexiones sobre deportes étnicos, identida des, políticas deportivas y promoción turística en las Islas Canarias (España), Retos, N uevas tendencias en educación física, deportes y recreación, 36, 480-486.

Anthony, D. (1966), SportandTourism, London, Central Council for Physical Recreation.

Cabanilla, E., LastraBravo, X, Pazmiño, J. \& Burbano, M. (2021). Análisis del perfil demográfico y consumo turístico en eventos deportivos en la ciudad de Q uito. Caso de estudio: Roger Federer, Retos, 40: 27-40. https:/ / doi.org/ 10.47197/ retos. v1i40.82749

Chalip, L. (2004). Beyond impact:A general model for sport event leverage, in B.W. Ritchie \& D. Adair (eds), Sport tourim: Interrelationships impacts and issues, Channel View, Clevedon, UK, 226-252.

Cruces, R. (2016). Crítica del turismo acceible. Desvelando la configuración discursiva y factual de los procesos de interación entre Turismo y Discapacidad. Elche: Universidad Miguel Hernández. https: / / www. educacion. es/ teseo/ mostrarRef. do?ref $=1311645$

Cunliffe, S. (2002). Forecasting risksin the tourism industry using the Delphi technique Tourism, 50 (1), 31-41.

Darcy, S. \& Dickson, T. (2009). A whole-of-life approach to tourism: the case for accessible tourism experiences, Journal of Hospitality and Tourism Management, volume 16 (1), 32-44.

DeKnop, P. (1990). Sport for all and active tourism, World Leisure\& Recreation, volume 32 (3), 30-36.

Downward, P. (2005). Critical (realist) reflection on policy and management research in sport, tourism and sports tourism, European Sport Management Quarterly, volume 5 (3), 302-322.

Fernández, M. T. \& Gutiérrez, E. P. (2014). Los eventos deportivos como dinamizadores turísticos: el caso del rally deAlgar en la provincia de Cádiz, Revista de estudios fronterizos del Estrecho de Gibraltar, volume 1, 1-20.

Fredline, L. (2005). Hostand guest relationsin sporttourism, Sport in Society, 8 (2), 263-279.

Gibson, H. (1998a). Sport Tourism: A Critical Analysis of Research, Sports Management Review, volume 1 (1), 4576.

Gibson, H. (1998b). Activesporttourism:W ho participates?, LesureStudies, 17 (2), 155-170.

Gibson, H. (2002). Sport tourism at a crossroad? Considerations for the future, in Gammon, $\mathrm{S}$. and Kurtzman, J. (eds), Sport tourism: principles and practice, LSA, Eastbourne, 111-122.

Gibson, H. (2004). Moving beyond the «what is and who» of sport tourism to understanding «why», Journal of Sport \&Tourism, volume9 (3), 247-265.

Gibson, H. J., W illming, C., \& Holdnak, A. (2003). Smallscale event sport tourism: fans as tourists, Tourism Management, 24, 181-190.

Gibson, H. J., W illming, C., \& Holdnak, A. (2008). Smallscale event sport tourism: fans as tourists, inWeed, $M$. (eds), Sport and Tourism: a reader, 0 xon, Routledge, 377392.

Glyptis, S. (1991). Sport and tourism, in. Cooper, C (eds.), Progress in tourism, recreation and hospitality management, Belhaven Press, London, 165-183.

González A brisketa, O. (2005). Pelota vasca: un ritual, una estética, Muelle de Uribitarte, Bilbao.

Hall, C. (1992), Hallmark tourist events. Belhaven Press, London.

Higham, J. (1999). Commentary - sport as an avenue of tourism development: an analysis of the positive and negative impacts of sport tourism, Current IssuesinTourism, 
2(1), 82-90.

Hinch, T. D. \& Higham, J. E. (2011), Sport tourism development (2nd edition), Channel View Publications, Bristol.

Hsu, C. \& Sandford, B. (2007).TheDeplhiTechnique: Making Sense of Consensus. Practical Assessment, Research and Evaluation, 12(10): 1-8. Available online: http:/ / pareonline net/ getvn. asp? $\mathrm{N}=12 \& n=10$ (accessed: $\mathrm{Dec}$. 29th, 2019).

Hudson, S. (1995). The' greening' of ski resorts: A necessity for sustainable tourism, or a marketing opportunity for skiing communities. Paper presented at the Leisure, Sportand Education - TheInterfacesAnnual Conference for the Leisure Studies Association, Eastbourne, UK.

Humberstone, B. J. (2000). The outdoor industry as social and educational phenomena: gender and outdoor adventure/ education, Journal of adventure education \& outdoor learning, 1(1), 21-35.

International Olympic Committee(IOC). (2018). Thenew norm: It's a game changer. https:/ / www. olympic. org/ news/ the-new-norm-it-s-argames-changer

Jackson, G.A. M., \&Weed, M. E. (2003). The sport-tourism interrelationship, in Houlihan, B. (eds), Sport and society, Sage, London.

Jiménez-Naranjo, H. V., CocaPérez, J. L., GutiérrezFernández, M. and Fernández-Portillo, A. (2016). Determinants of the expenditure done by attendees at a sporting event: the case ofWorld Padel Tour, European Journal of Management and Business Economics, 25(3), 133141.

Keller, P., Breiter, M. Duc, N. \& Salamin, F. (2002). Sport and tourism. World Tourism O rganization, Madrid.

Kennelly, M . \& Toohey, K. (2014). Strategic alliances in sport tourism: national sport organisations and sport tour operators, Sport management review, 17, 407-418.

Kim, W., Jun, H. M., Walker, M. \& Drane, D. (2015). Evaluating the perceived socia impacts of hosting largescale sport tourism events: scale development and validation, Tourism management, 48, 21-32.

Kirby, S., Duignan, M., \& McGillivray, D. (2018) Mega sport events, micro and small business leveraging: introducing the «MSE-MSB leverage model», Event Management, 22: 917-931. https:/ / doi.org/ 10.3727/ $152599518 \times 15346132863184$

Latiesa, M. \& Paniza, J. L. (2006), Turistas deportivos: Una perspectiva de análisis, Revista Internacional de Sociología, 44(64), 133-149.

Lesjak, M., Podovšovnik, E., \& U ran, M. (2014) The Perceived Social Impacts of the EuroBasket 2013 on Koper Residents, Academica Turistica, 7: 53-68.

Linstone, H. \&Turoff, M. (2002, orig. 1975). Introduction.
In Linstone, H. \& Turoff, M. (eds)The Delphi M ethod. TechniquesandApplication. Reading (M ass):Addison-Wesley Pub. Available online: http:/ / www. is. njit. edu/ pubs/ delphibook/ ch1.pdf (accessed: March. 28th, 2019).

Lisbona, M., Medina, F. X. \& Sánchez, R. (2008). El turismo deportivo: visiones críticas sobre posibilidades de desa rrollo local en Españay M éxico, in Cantero, L., M edina, F. X. \& Sánchez, R. (coords.), Actualidad en el deporte: invesigación y aplicación, Ankulegi AntropologiaElkartea, Donostia.

Mair, J., Chien, P.M., Kelly, S.J. \& Derrington, S. (2021) Social impacts of mega events: a systematic narrative review and research agenda, Journal of SustainableTourism, 1(22). https:/ / doi. org/ 10.1080/ 09669582.2020 .1870989

McGillivray, D., Duignan, M. \& Mielke, E. (2019) Mega sporteventsand spatial management: zoning spaceacross Rio's 20160 lympic city, Annals of Lesure Research, 23(3): 280-303. https:/ / doi. org/ 10.1080/ 11745398.2019 .1607509

M cKenna, H.P. (1994)The Delphi technique: a worthwhile research approach for nursing?, Journal of Advanced N ursing, 19(6), 1221-1225.

Medina, F. X. (2006). Los Juegos M editerráneos: Diálogo, política internacional y promoción socioeconómica, $R e$ vista de Dialectología y Tradiciones Populares, LXI(2), 225238.

M edina, F. X. \& Sánchez, R. (2002). Diez años de revistas antropológicasen España(1990-2000). Unaevaluación, Revista deD ialectología yTradicionesPopulares(RDTP), LVII(1), 11-28.

Medina, F. X. \& Sánchez, R. (2004). Deporte, turismo y desarrollo local, Studium. Revista dehumanidades, 10, 183196.

M edina, F. X. \& Sánchez, R. (2005). A ctividad físico-deportiva, turismo y desarrollo local en España, Pasos 3 (1), 97-107.

M edina, F. X.\& Sánchez, R. (2006). Introducción, Laantropología del deporte en España. Visión crítica y perspectivas de futuro, Revista de D ialectología y Tradiciones Populares(RDTP), LXI(1), 7-17.

Merino Mandly, A. (1998). Planteamiento y orientación del Encuentro de estudio sobre el Turismo en Andalucía, 1998, in Primer Encuentro de Estudios sobreTurismo deportivo en Andalucía, Málaga, IAD, 23-24 de octubre (unpublished).

Meyer, E. (1993). Theimpact of summer and winter tourism on the fauna of al pine soils in western Austria (O etztal Alps, Raptikon), Revue Suissede Zoologie, 100, 519-527. Nogawa, H.,Yamguchi,Y., \& Hagi,Y. (1996). An empirical 
research study on Japanese sport tourism in Sport-forAll Events: Case studies of a single-night event and a multiple-night event, Journal of Travel Research, 35, 4654.

Nogueira Mendes, R.M , FaríasTorbidoni, E.I. \& Pereira da Silva, C. (2021) Eventos de bicicleta de montanha em Portugal: características, distribuição tempora e espa cial e ocorrência sobre a rede nacional de áreas protegidas e classificadas, Retos, 39, 216-223. https:/ / doi.org/ 10.47197/ retos. v0i39. 78368

Nogués-Pedregal, A., Travé-M olero, R., \& CarmonaZZubiri, D. (2017), «Thinking against 'empty shells' in tourism development projects», Etnoloska Tribina, 40(47), 88-108. https:/ / doi.org/ 10.15378/ 1848-9540.2017.40.02

Peric, M . (2018) Estimating the Perceived Socio-Economic Impacts of Hosting Large-Scale Sport Tourism Events, Social Sciences, 7(10), 176. https:/ / doi.org/ 10.3390/ socsci7100176

Pigeassou, C. (2004). Contribution to the definition of sport tourism, Journal of sport and tourism, 2004, 287-289.

Redmond, G (1990). Points of increasing contact: Sport and tourism in the modern world, in Tomlinson, A. (eds.), Proceedings of the LeisureStudiesAssociation Second International Conference, Leisure, Labour, and Lifestyles: International Comparisons, ConferencePapersno. 43. LSA Publications, Eastbourne, UK, 158-169.

Redmond, G. (1991). Changing styles of sports tourism: Industry/ consumer interactions in Canada, the USA, and Europe, in M.T. Sinclair and M.J. Stabler (eds), The tourism industry: An international analysis Wallingford, UK: CAB International, pp. 107-120.

Sánchez-Bergara, S.; Leal-Londoño, M.P.; Medina, F.X.; Mansilla, J.; Travé-M olero, R.; Milano, C. \& Soro, E. (2018). SportTourism as adriver for Cultural andTerritoria Identity. Reflections on Methodological Aspects of a Research in Progess, International Journal of Scientific Management andTourism, 4(1), 485-494.

Scheu, A. \& Preuss, H. (2018) Residents' perceptions of mega sport event legacies and impacts. The case of the Hamburg 2024 Olympic bid, German Journal of Exercise and Sport Research, 48, 376-386. https:/ / doi.org/ 10.1007/ s12662-018-0499-y

Standeven, J. , \& DeK nop, P. (1999) SportTourism. Champaign (III.), Human Kinetics.

Thomson, A., Cuskelly, G., Toohey, K., Kennelly, M., Burton, P. \& Fredline, L. (2019) Sport event legacy: A systematic quantitativereview of literature, Sport M anagement Review, 22(3), 295-321. https:// doi.org/ 10.1016/ j.smr.2018.06.011

Turco, D., \& Eisenhardt, H. (1998). Exploring the sport tourism connection, ICH PER SD , 24-27.

United NationsWorldTourism O rganization. (1999). Global Code of Ethics. Retrieved July 8, 2019, from http:/ / ethics. unwto.org/content/ global-code-ethics-tourism

United Nations World Tourism O rganization. (2016). Da $N$ ang Dedaration on promoting tourismand sportsfor susainable development. Retrieved July 8, 2019, from http:// vietnamtourism. gov. vn/ english/ index. php/ items/ 11011

Van Rheenen, D., Cernaiznu, S. \& S Sobry, C. (2016). Defining sport tourism: a content analysis of an evolving epistemology. Journal of Sport \& Tourism, 21(2), 7593. https:/ / doi.org/ 10.1080/ 14775085.2016.1229212 Walo, M., Bull, A., \& Breen, H. (1996). A chieving economic benefits at local events: A case study of a local sports event, Festival M anagement and Event Tourism, 4, 95-106.

W äsche, H. (2015). Interorganizational cooperation in sport tourism: asocial network analysis, Sport management review, 18, 542-554.

Weed, M. (1999). More than sports holidays: an overview of the sport-tourism link. Proceedings of a SPRIG Seminar held at the University of Sheffield, pp. 6-28

Weed, M. (2006). SportsTourism Research 2000-2004: A Systematic Review of K nowledgeand aM etaEvaluation of M ethods, Journal of Sport \& Tourism, 11 (1), 5-30.

Weed, M. (2008), Olympic tourism. Elsevier Ltd., Burlington.

Weed, M. (2009). Progress in sports tourism research? A meta-review and exploration of futures, Tourism Management, 30, 615-628.

Weed, M. E., \& Jackson, G. A. M. (2008). The relationship between sport and tourism, in Houlihan, B. (eds), Sport and society. Sage, London, 395-414.

Weed, M. E., and Bull, C. J. (2004), Sportstourism: Participants, policy \& providers, Elsevier, Oxford.

Williams, A. \& Zelinsky, W. (1970). On some patterns in international tourist flows, Economic Geography, 46, 549567.

WorldTravel \& Tourism (2019). Economic Impact. Retrieved July 8, 2019, from https:/ / www.wttc. org/ economicimpact/

Yildiz, Z. \& Çekiç, S. (2015). SportTourism and its History and Contribution of Olympic Games to Touristic Promotion, International journal of ScienceCultureand Sport, 3(12): 326-326

Zhou, R. \& Kaplanidou, K. (2018) Building social capital from sport event participation: An exploration of the social impacts of participatory sport events on the community, Sport management review, 21(5): 491-503. https:/ / doi.org/ 10.1016/ j.smr.2017.11.001 